\title{
Application of Assessment Models for Health Risk and Pollution From Surface Water From Okumpi River in Nwangele, Imo State, Nigeria
}

Ihenetu chukwuemeka Stanley ( $\sim$ lhenetustanley@yahoo.com )

Imo State University https://orcid.org/0000-0002-5412-3853

Njoku Obinna

Imo State University Faculty of Science

Ibe Chizoruo

Imo State University Faculty of Science

\section{Research Article}

Keywords: Models for Health Risk, Surface Water, Okumpi River, Imo State, Nigeria, risk of water

Posted Date: April 27th, 2021

DOI: https://doi.org/10.21203/rs.3.rs-453225/v1

License: (c) This work is licensed under a Creative Commons Attribution 4.0 International License.

Read Full License 


\title{
APPLICATION OF ASSESSMENT MODELS FOR HEALTH RISK AND POLLUTION FROM SURFACE WATER FROM OKUMPI RIVER IN NWANGELE, IMO STATE, NIGERIA
}

\author{
Ihenetu Stanley Chukwuemeka, Njoku Victor Obinna and Ibe Francis Chizoruo \\ Department of Chemistry, Imo State University Owerri Nigeria \\ Corresponding author: Ihenetustanley@yahoo.com
}

\begin{abstract}
The study targets at examining the pollution assessment and environmental health effects of surface water from Okumpi River. Ten surface water samples were collected randomly both in wet and dry seasons within the river that was assessed. The models used for assessment include contamination factor (Cf), pollution load index (PLI), water quality index, dermal and absorption exposure dose, hazard quotient (HQ), hazard index (HI) and carcinogenic risk (CR). The mean and standard deviation $\mathrm{pH}$ value in the present study during the wet and dry seasons varied from $6.21 \pm 0.22-5.75 \pm 0.41$. The mean and standard deviation EC in the current study ranges between $219.15 \pm 12.20-193.30 \pm 14.81 \mu \mathrm{S} / \mathrm{cm}$ for wet and dry seasons which are found to be in line with the WHO standard used. The mean and standard deviation of DO for this study during the wet and dry seasons were found to be $10.03 \pm 0.58-6.47 \pm 0.41(\mathrm{mg} / \mathrm{L})$. TDS for wet and dry seasons ranges from $374.79 \pm 5.33-121.65 \pm 6.33 \mathrm{mg} / \mathrm{L}$. The colour of the water samples at both seasons were lower than the permissible limit 9.60 $\pm 0.89-11.20 \pm 3.11$ PCU against 15 PCU used as the standard. The nitrate [9.05 \pm 1.08 - 8.09 \pm 1.57$]$, sulphate [3.91 $\pm 0.51-3.73 \pm 0.46]$ and phosphate $[82.78 \pm 3.86$ - 81.76 \pm 3.32$]$ in this present study for wet and dry season were all found to be below the standard of WHO for safe drinking water. Among all the heavy metals studied, Iron [1.28 $\pm 0.01-0.37 \pm 0.01$ $(\mathrm{mg} / \mathrm{L})]$ and Nickel $[0.98 \pm 0.04-1.03 \pm 0.04(\mathrm{mg} / \mathrm{L})]$ were found more in the study in wet and dry seasons while cadmium was not detected in both seasons. Nickel showed high contamination factor of $48.24-42.40$ in wet and dry season while cupper showed the least contamination factor of $0.012-0.008$ in wet and dry season. The study has revealed that the surface water is not suitable for drinking purposes as seen by the high water quality index which the calculated value gave 1205.56-1236.26 for wet season and dry season which is $>300$. The Hazard quotient via ingestion and Hazard quotient via dermal has a reduction in the order of lead $>$ nickel $>$ iron $>$ manganese $>$ copper $>$ zinc and lead $>$ zinc $>$ nickel $>$ copper $>$ iron $>$ manganese $>$ cadmium, in cooperation in children and adults in wet season, correspondingly. The Hazard quotient via ingestion and Hazard quotient via dermal has a decrease in the following order of nickel $>$ lead $>$ manganese $>$ copper $>$ iron > zinc and lead > zinc > nickel > copper > manganese $>$ iron $>$ for both children and adults in dry season, respectively. Lead possess carcinogenic risk for the inhabitants of this area due to the value of the carcinogenic risk $n$ wet season of 4.05E-4 in adult and 1.55E-3 in children, in dry season of 2.57E-4 in adult and 9.88E-4 in children, against the standard set by the USEPA of $10^{-6}$ $-10^{-4}$. The water pollution monitoring agency of this area should regularly check the water quality assessment of this river and should suggest treatment through filtration, boiling and the use of additives in order to reduce the risk of water related problems.
\end{abstract}

\section{Introduction}

Man and its environment are blessed with the most fundamental yet least expensive asset of earth, which are found all over. Notwithstanding, because of botch and less undertaking conduct of man, the most valuable asset has been severally been contaminated with physiochemical tracer and 
through anthropogenic exercises (Ihenetu et al., 2020). Water pollution transpires when water is adulterated with chemicals and foreign bodies that are destructive to animals, plants and humans. Water pollutants take account of chemical contamination which comes from waste places and sites, chemical wastes from industrial discharges, also heavy metals and materials such as lead and mercury, food processing waste, sewage waste, pesticides and fertilizers (Gannon et al., 2007). In rural areas, the major source of water pollution can be directed to anthropogenic activates and runoff from agricultural farm lands surrounding the rivers. Most works done by researchers are mostly concentrated on the urban areas meanwhile the source of domestic and livelihood of rural people are based in these surface water which they consume without the prior knowledge of the water quality. Water pollution is a severe ecological menace. When contaminated water is taken, it poses a very harmful to animal health and human. When toxic constituents dissolve in bodies of water of every type such as oceans, lakes and rivers, the water becomes polluted. They reduce the quality of water over interval. This results in devastating effects to aquatic ecosystems. Pollutants always contaminate the groundwater, which stances a serious danger to households that use the contaminated water (Jinwal and Dixit, 2008). Surface waters include streams, reservoirs, lakes, rivers, and wetlands. Surface water comes mostly from rainfall and is an amalgamation of the surface run-off and ground water. (Bernice et al., 2013). Unintended urbanization and population progression are among some of the home made and domestic activities accountable for pollution of water bodies. Stream flow varies in response to climatic factors and human activities (Owa, 2013).

Anudike et al., (2019) worked on the Water quality assessment of Nwangele River in Imo State, Nigeria and found out that the river is slightly polluted and the present river studied has a flow with Nwangele River. Ubuoh et al., (2013) researched on the effectiveness of water quality index in Izombe in Imo state of Nigeria. The scientific research was done in Region where gas flaring is unremitting in order to establish pollution level in rainwater and boreholes as they are seen as the two major foundations of water supply in the area. The concentration of pollution among the sampled water resources was achieved by comparing the outcome of physicochemical tracers with that of WHO standards for drinking water. This research work frames a benchmark for the assessment of water quality in Okumpi River situated in Nwangele Local Government area of Imo state Nigeria since no work has been done in this river for physicochemical and health risk assessment. The objective of this work is to survey the physiochemical attributes and human health assessment because of heavy metals in surface waters sources in the study area.

\section{RESEARCH DESIGN}

\section{Study Area}

The study area is Okumpi River located in Nwangele Local Government area of Imo State. The geology of Nwangele area comprises of plain soil which is about $0.05-2.0 \mathrm{~mm}$ in size and it is somewhat porous, deep and highly leached. Geographically, the area falls between coordinates of latitude 5.7358785479-5.7410154879 and longitude 7.12223658951-7.12874785412. The major occupation in these areas include farming, fishing with few traders. The activities carried out in these rivers include washing of cloths, fishing, washing and fermentation of agricultural products, washing of kitchen utensils, bathing etc. Nwangele is in the tropical rainforest zone and it has two distinctive seasonal variation which are the wet and dry the seasons. Figure 1 below shows the map of the sampling point and the study area. The wet season twitches from April through October 
with topmost incidence between June and September while the dry season launches in November through March annually.

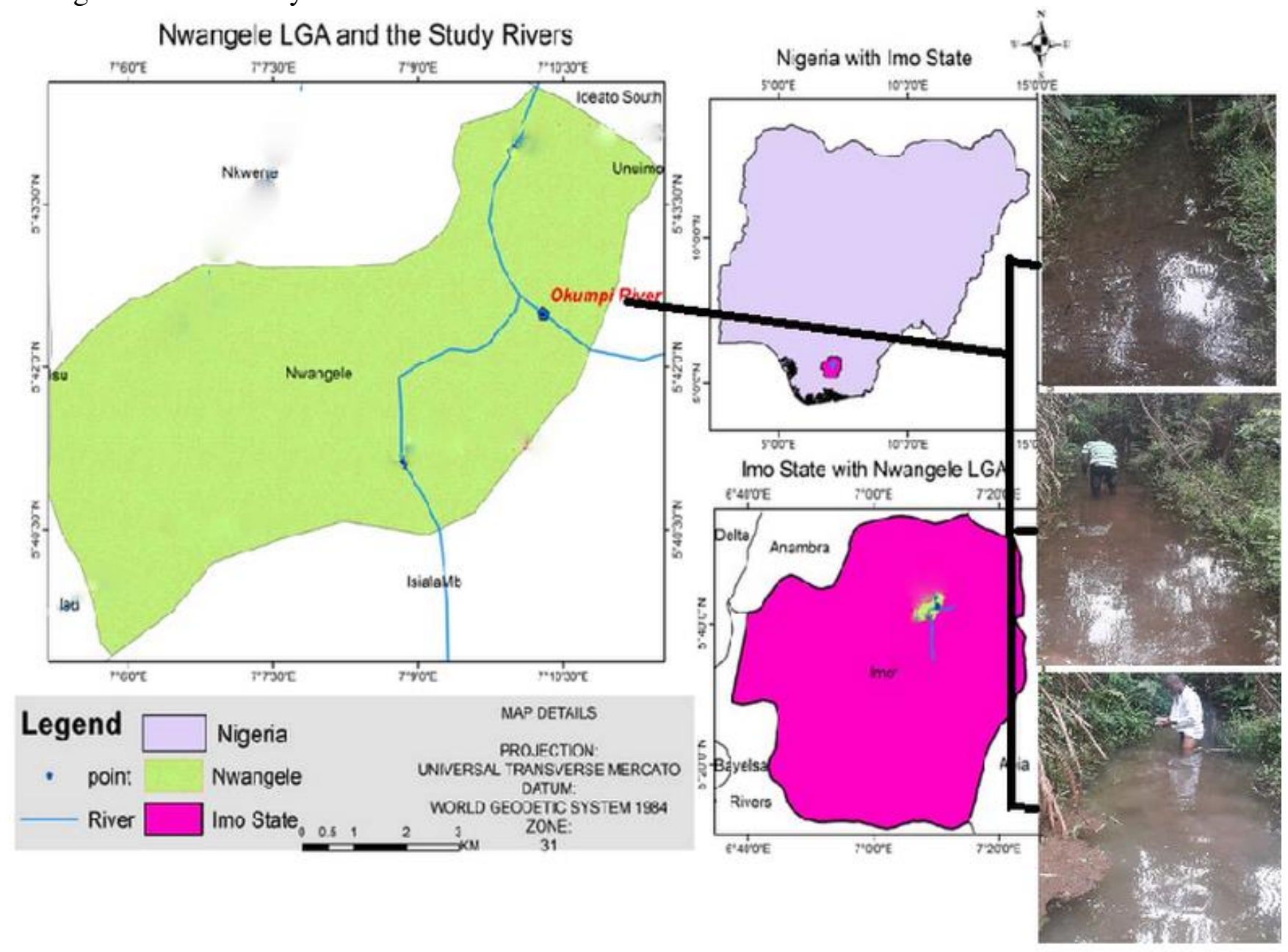

Figure 1: Map showing Okumpi River

\section{Sample Collection}

Ten surface water samples were collected randomly both in wet and dry seasons within the river that was assessed. Sampling in this area was carried out for both dry and wet seasons and specified as Okw and Okd respectively. 500mL polyethylene sample containers were used to collect water samples from the River. In the sampling point, the containers were rinsed three times with water at the sampling point before the collection of the samples. The water samples were collected according to the method used by Ihenetu et al., (2019).

\section{Laboratory Analysis of surface water samples}

The surface water samples were analyze for the following: Electrical conductivity (EC), $\mathrm{pH}$, Dissolved Oxygen (DO), Total dissolved solid (TDS), Temperature, colour, Odour, Calcium (Ca), Sodium $(\mathrm{Na})$, Potassium $(\mathrm{K})$, Phosphate $\left(\mathrm{PO}_{4}{ }^{3-}\right)$, Nitrate $\left(\mathrm{NO}_{3}{ }^{2-}\right)$, Sulphate $\left(\mathrm{SO}_{4}{ }^{2-}\right), \mathrm{Lead}(\mathrm{Pb})$, Copper $(\mathrm{Cu})$, Iron $(\mathrm{Fe})$, Nickel (Ni), Manganese (Mn), Zinc ( $\mathrm{Zn})$ and Cadmium $(\mathrm{Cd})$. 


\section{Instrumentation}

The electrical conductivity was measured using the HANNA HI8733 EC METER in $\mu$ S/cm, the $\mathrm{pH}$ was measured using JENWAY 3510pH METER, the DO concentration of the surface water samples were established using a Jen-way 9071 digital oxygen analyzer, colour and anion determination were done using Multiparameter bench photometer HI 82300 by HANNA Instruments. TDS were determined using Groline TDS meter by HANNA Instruments. Calcium, sodium, potassium, iron, copper, cadmium, Nikel, Manganese, Zinc, and lead, in the respective surface water samples was determined using Perkins Elmer AAnalyst 400 Atomic Absorption Spectrophotometer (WHO, 2004).

\section{Data Analysis}

The data were assessed for their mean and standard deviation. The data were used to calculate the pollution index models and contamination also Spear-man's correlation coefficient, water quality index (WQI) analysis and health risk assessment were calculated.

\section{Quality control}

Reagents used throughout the experiments were of high quality analytical grade, which was purchased from BDH Chemical Ltd, UK, and Sigma- Aldrich Chemie GmbH, Germany. Detergents and deionized water were used to wash the glassware and sample bottles. They were soaked overnight with a solution of $10 \% \mathrm{HNO}_{3}$ in a $1 \% \mathrm{HCl}$ solution, followed by rinsing with deionized water. Similarly, the reagents that were used for the determination of anion concentrations with the Hanna Hi 83,200 Instrument were obtained from Hanna Instruments. The instrument (Agilent 240FS AA) used for the determination of the concentrations of metallic elements in the samples has high sensitivity - typically > 0.9 absorbance with a precision of < $0.5 \% \mathrm{RSD}$ from ten-second integrations for $5 \mathrm{mg} / \mathrm{L} \mathrm{Cu}$ standard. 


\section{Results and Discussion}

Physicochemical parameters of surface water

Table 1: Values of Water Quality Parameters in the multiple studies in wet season

\begin{tabular}{|c|c|c|c|c|c|c|c|c|c|c|c|c|c|}
\hline & Wet & & & & & & Dry & & & & & & \\
\hline Parameters & Okw $_{1}$ & $\mathrm{Okw}_{2}$ & $\mathrm{Okw}_{3}$ & $\mathrm{Okw}_{4}$ & $\mathrm{Okw}_{5}$ & Mean \pm Std & Okd $_{1}$ & Okd $_{2}$ & $\mathbf{O k d}_{3}$ & $\mathrm{Okd}_{4}$ & Okd $_{5}$ & Mean \pm Std & WHO 2004/2006 \\
\hline Temp $\left({ }^{\mathrm{O}} \mathrm{C}\right)$ & 25.41 & 25.52 & 25.47 & 25.58 & 25.47 & $25.49 \pm 0.06$ & 27.81 & 28.68 & 27.08 & 28.45 & 27.65 & $27.93 \pm 0.61$ & $20-30$ \\
\hline DO (mg/L) & 9.90 & 10.04 & 10.09 & 10.87 & 9.24 & $10.03 \pm 0.58$ & 6.87 & 6.24 & 6.98 & 6.17 & 6.11 & $6.47 \pm 0.41$ & 10.0 \\
\hline $\mathrm{EC}(\mu \mathrm{S} / \mathrm{cm})$ & 227.31 & 231.76 & 224.15 & 203.71 & 208.83 & $219.15 \pm 12.20$ & 203.71 & 208.83 & 198.80 & 176.04 & 179.14 & $193.30 \pm 14.81$ & 2500 \\
\hline $\mathrm{pH}$ & 6.34 & 6.39 & 6.36 & 6.07 & 5.90 & $6.21 \pm 0.22$ & 6.07 & 5.90 & 6.16 & 5.22 & 5.41 & $5.75 \pm 0.41$ & $6.50-8.50$ \\
\hline TDS (mg/L) & 136.39 & 139.04 & 134.49 & 124.91 & 133.11 & $374.79 \pm 5.33$ & 124.91 & 129.11 & 124.14 & 115.6 & 114.47 & $121.65 \pm 6.33$ & 500 \\
\hline Col (PCU) & 11.00 & 9.00 & 9.00 & 10.00 & 9.00 & $9.60 \pm 0.89$ & 10.00 & 9.00 & 8.00 & 14.00 & 15.00 & $11.20 \pm 3.11$ & 15 \\
\hline $\mathrm{NO}_{3}^{-}(\mathrm{mg} / \mathrm{L})$ & 8.84 & 9.92 & 7.41 & 8.93 & 10.14 & $9.05 \pm 1.08$ & 8.93 & 10.14 & 8.03 & 7.37 & 5.98 & $8.09 \pm 1.57$ & 50 \\
\hline $\mathrm{PO}_{4}^{2-}(\mathrm{mg} / \mathrm{L})$ & 82.74 & 80.00 & 89.40 & 81.63 & 80.14 & $82.78 \pm 3.86$ & 81.63 & 80.14 & 87.50 & 79.20 & 80.35 & $81.76 \pm 3.32$ & 1.0 \\
\hline $\mathrm{SO}_{3}{ }^{2-}(\mathrm{mg} / \mathrm{L})$ & 3.74 & 4.41 & 3.19 & 3.81 & 4.40 & $3.91 \pm 0.51$ & 3.81 & 4.40 & 3.32 & 3.25 & 3.87 & $3.73 \pm 0.46$ & 250 \\
\hline $\mathrm{Ca}(\mathrm{mg} / \mathrm{L})$ & 4.09 & 4.12 & 4.13 & 3.88 & 3.96 & $4.04 \pm 0.11$ & 3.88 & 3.96 & 4.03 & 4.10 & 3.98 & $3.99 \pm 0.08$ & 75 \\
\hline $\mathrm{Na}(\mathrm{mg} / \mathrm{L})$ & 5.27 & 5.07 & 5.31 & 5.03 & 4.87 & $5.11 \pm 0.18$ & 5.03 & 4.87 & 5.08 & 5.47 & 4.99 & $5.09 \pm 0.22$ & 200 \\
\hline $\mathrm{K}(\mathrm{mg} / \mathrm{L})$ & 4.99 & 5.01 & 5.03 & 4.58 & 4.89 & $4.90 \pm 0.61$ & 4.58 & 4.89 & 4.92 & 5.44 & 4.36 & $4.84 \pm 0.41$ & 20 \\
\hline $\mathrm{Fe}(\mathrm{mg} / \mathrm{L})$ & 1.64 & 1.37 & 1.41 & 1.09 & 0.98 & $1.28 \pm 0.01$ & 0.71 & 0.08 & 0.10 & 0.40 & 0.6 & $0.37 \pm 0.01$ & 0.3 \\
\hline $\mathrm{Cu}(\mathrm{mg} / \mathrm{L})$ & 0.02 & 0.01 & 0.00 & 0.02 & 0.01 & $0.01 \pm 0.01$ & 0.02 & 0.01 & 0.01 & 0.02 & 0.01 & $0.01 \pm 0.01$ & 2.00 \\
\hline $\mathrm{Cd}(\mathrm{mg} / \mathrm{L})$ & 0.00 & 0.00 & 0.00 & 0.00 & 0.00 & $0.00 \pm 0.0$ & 0.00 & 0.00 & 0.00 & 0.00 & 0.00 & $0.00 \pm 0.0$ & 0.003 \\
\hline Ni (mg/L) & 1.01 & 0.93 & 0.94 & 1.03 & 1.00 & $0.98 \pm 0.04$ & 1.03 & 1.00 & 1.02 & 1.11 & 1.00 & $1.03 \pm 0.04$ & 0.02 \\
\hline $\mathrm{Mn}(\mathrm{mg} / \mathrm{L})$ & 0.03 & 0.01 & 0.02 & 0.03 & 0.02 & $0.02 \pm 0.01$ & 0.03 & 0.02 & 0.03 & 0.04 & 0.03 & $0.03 \pm 0.01$ & 0.4 \\
\hline $\mathrm{Zn}(\mathrm{mg} / \mathrm{L})$ & 0.34 & 0.29 & 0.29 & 0.09 & 0.08 & $0.22 \pm 0.12$ & 0.09 & 0.08 & 0.08 & 0.60 & 0.09 & $0.19 \pm 0.23$ & 3.00 \\
\hline $\mathrm{Pb}(\mathrm{mg} / \mathrm{L})$ & 0.13 & 0.14 & 0.15 & 0.07 & 0.07 & $0.11 \pm 0.03$ & 0.07 & 0.07 & 0.08 & 0.07 & 0.05 & $0.07 \pm 0.01$ & 0.01 \\
\hline
\end{tabular}


Temperature of water centers on its proposed usage. The temperature of surface water, conferring to the standards used falls within $20-30^{\circ} \mathrm{C}$ (WHO, 2006). The temperature degree examined for the wet season and dry seasons where observed to be within the WHO and NSDWQ standards. Nevertheless the dry season in the study revealed a minor upsurge in temperature which possibly will be due to the current weather condition of the environment at the location of study. Decrease and increase in temperature level is one of the notable importance feature of seasonal variation and weather change. Dissolve oxygen is the oxygen present in dissolve form in water bodies (Ibe $e t$ al., 2019). Its decrease is ominously affected by runoff from agricultural farm lands and soils encompassing nitrogen and phosphate compounds or the death and decay of marine life forms leading to the release of nitrogen compound directly to the water body subsequently causing decrease in dissolve oxygen. According to WHO standard, the dissolve oxygen for all points during the wet season were found to be low in relation to dry season, the DO is found to be lesser than the standards for dry season but slightly higher during the wet season $[10.03 \pm 0.58-6.47 \pm 0.41$ $(\mathrm{mg} / \mathrm{L})]$. The thin increase in DO and $\mathrm{pH}$ during the wet season can be studied in line with the affectation by similar anthropogenic activities. Interrelated results were noticed for Nworie River (Duru and Nwanekwu, 2012). The EC can critically affect the taste of water. The EC in this study falls between $219.15 \pm 12.20-193.30 \pm 14.81 \mu \mathrm{S} / \mathrm{cm}$ in wet and dry season. The values obtained were contained by the WHO standard for risk-free drinking water. The $\mathrm{pH}$ value in this study for the two seasons varied from $6.21 \pm 0.22-5.75 \pm 0.41 \mu \mathrm{S} / \mathrm{cm}$ which shows a little acidity which were not in agreement to the standard $\mathrm{pH}(6.50-8.50)$ recorded by WHO $(2004,2006)$ guidelines for safe drinking water.

In this present study, the TDS for the wet and dry season fall between $374.79 \pm 5.33-121.65 \pm 6.33$ $\mathrm{mg} / \mathrm{L}$. This might perhaps will be a suggestion of normal pollution from overflow of soils within the study area. The colour of the water samples at all the sampling sites were lower than the allowable $(9.60 \pm 0.89-11.20 \pm 3.11$ PCU). The nitrate [9.05 $\pm 1.08-8.09 \pm 1.57]$, sulphate [3.91 \pm 0.51 - 3.73 \pm 0.46$]$ and phosphate [82.78 $\pm 3.86-81.76 \pm 3.32]$ in this present study for wet and dry season were all found to be below standard of WHO standard for safe drinking water. Comparable findings were detected in sulphate and nitrates values obtained from study carried out on Nwangele River (Ihenetu et al., 2020). Calcium, sodium and potassium as found from the current study in both seasons are below the WHO standard.

The plotted distribution of heavy metals are presented in Figures 2, with error bars which represent the standard bar. Cadmium was not detected in all the sampling points in both seasons. Among all the heavy metals studied, Iron [1.28 $\pm 0.01-0.37 \pm 0.01(\mathrm{mg} / \mathrm{L})]$ and Nickel $[0.98 \pm 0.04-1.03 \pm 0.04$ $(\mathrm{mg} / \mathrm{L})]$ were found more in the study while cadmium was not detected in both season. Nickel showed high contamination factor of $48.24-42.40$ in wet and dry season while cupper showed the least contamination factor of $0.012-0.008$ in wet and dry season. 


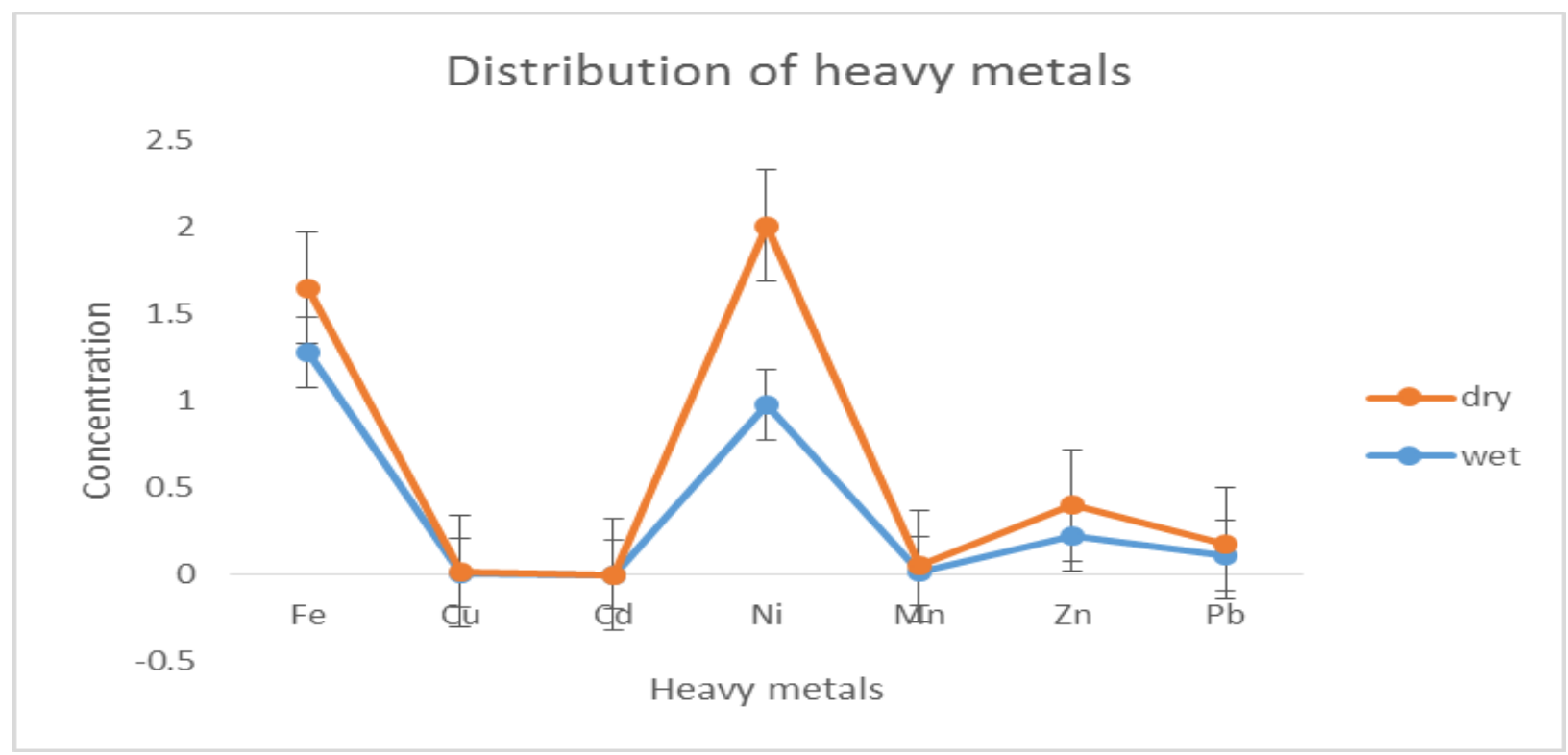

Figure 2: Line chart with error bars showing the distribution of heavy metal in wet and dry seasons

The iron level was high during the wet season and this might be as a result of iron coagulants and also due to the fact that most mineral sediment on the soil may have high level of iron. (Macdonald and Christopher, 2011). Copper is an essential nutrient, however, it can also be a contaminant if seen in higher concentration. The low level of copper in this present study is in line with the result observed in Nwangele River (Anudike et al., 2019) and in River Nworie (Duru and Nwanekwu, 2012). With regards to WHO standard for household and drinking water value for Mn, all points for wet season showed low level of $\mathrm{Mn}$. If $\mathrm{Mn}$ is found higher in water, it can constitute an irritation with a characteristic metallic taste and discoloration properties (Ugwu, 2016). The level of zinc observed in this present study are below the standard used for checking the level of good water quality unlike lead which is higher during the dry season on this present study $(0.1 \mathrm{mg} / \mathrm{L})$, this might be due to the disbanding of lead from the soil.

\section{Correlation coefficient matrix}

A substantial positive correlation $(\mathrm{r}>0.5)$ was observed between some of the metals, and anions parameters. The coefficient of relationship is shown in Table 2. All metals showed negative association/relationship with Copper and Cadmium. Nevertheless, significant positive relations during the wet season were exhibited between $\mathrm{NO}_{3}-/ \mathrm{SO}_{4}{ }^{2-}(0.99), \mathrm{PO}_{4}{ }^{2-} / \mathrm{Na}(0.76), \mathrm{PO}_{4}{ }^{2-} / \mathrm{Pb}$ (0.55), $\mathrm{Ca} / \mathrm{Na}$ (0.68), $\mathrm{Ca} / \mathrm{K}$ (0.93), $\mathrm{Ca} / \mathrm{Fe}$ (0.78), $\mathrm{Ca} / \mathrm{Zn}$ (0.91), $\mathrm{Ca} / \mathrm{Pb}(0.96), \mathrm{Na} / \mathrm{Fe}$ (0.87), Na/Zn (0.83), Na/Pb (0.80), K/Fe (0.62), K/Zn (0.76), K/Pb (0.80), Fe/Zn (0.96), Fe/Pb (0.83), Ni/Mn (0.86) and $\mathrm{Zn} / \mathrm{Pb}$ (0.94). Significant positive associations through the dry season were exhibited between $\mathrm{NO}_{3}-/ \mathrm{SO}_{4}{ }^{2-}(0.51), \mathrm{NO}_{3}-/ \mathrm{Pb}(0.60), \mathrm{PO}_{4}{ }^{2-} / \mathrm{Pb}(0.59), \mathrm{Ca} / \mathrm{Na}(0.74), \mathrm{Ca} / \mathrm{K}(0.75), \mathrm{Ca} / \mathrm{Ni}$ (0.64), $\mathrm{Ca} / \mathrm{Mn}$ (0.60), $\mathrm{Ca} / \mathrm{Zn}$ (0.74), Na/K (0.75), Na/Cu (0.65), Na/Ni (0.97), Na/Mn (0.93), Na/Zn (0.94), K/Ni (0.80), K/Zn (0.81), K/Pb (0.58), $\mathrm{Fe} / \mathrm{Cu}(0.56), \mathrm{Cu} / \mathrm{Ni}(0.76), \mathrm{Cu} / \mathrm{Mn}(0.64), \mathrm{Cu} / \mathrm{Zn}$ (0.62), Ni/Mn (0.85), Ni/Zn (0.95) and Mn/Zn (0.79). Once the correlation is seen positive, the foundation of contamination of the positively linked metals is alike while negative correlation recommend dissimilar/different bases of contamination. Notable pollution can be through washing of engine cars, tricycles and motor cycles at the river. Some of the relationship shown by the metals has been examined by (Verla et al., 2018). 
Table 2: Correlation coefficient matrix heavy metals and anions in wet/dry season

\begin{tabular}{|c|c|c|c|c|c|c|c|c|c|c|c|c|c|}
\hline Wet & $\mathrm{NO}_{3}^{-}$ & $\mathrm{PO}_{4}{ }^{2-}$ & $\mathrm{SO}_{4}{ }^{2-}$ & $\mathrm{Ca}$ & $\mathrm{Na}$ & K & $\mathrm{Fe}$ & $\mathrm{Cu}$ & $\mathrm{Cd}$ & $\mathrm{Ni}$ & $\mathrm{Mn}$ & $\mathrm{Zn}$ & $\mathrm{Pb}$ \\
\hline $\mathrm{NO}_{3}^{-}$ & 1 & & & & & & & & & & & & \\
\hline $\mathrm{PO}_{4}{ }^{2-}$ & -0.95 & 1 & & & & & & & & & & & \\
\hline $\mathrm{SO}_{4}{ }^{2-}$ & 0.99 & -0.92 & 1 & & & & & & & & & & \\
\hline $\mathrm{Ca}$ & -0.32 & 0.44 & -0.24 & 1 & & & & & & & & & \\
\hline $\mathrm{Na}$ & -0.82 & 0.76 & -0.81 & 0.68 & 1 & & & & & & & & \\
\hline K & -0.13 & 0.32 & -0.07 & 0.93 & 0.47 & 1 & & & & & & & \\
\hline $\mathrm{Fe}$ & -0.44 & 0.39 & -0.43 & 0.78 & 0.87 & 0.62 & 1 & & & & & & \\
\hline $\mathrm{Cu}$ & 0.36 & -0.60 & 0.26 & -0.53 & -0.19 & -0.57 & 0.02 & 1 & & & & & \\
\hline $\mathrm{Cd}$ & 0 & 0 & 0 & 0 & 0 & 0 & 0 & 0 & 1 & & & & \\
\hline $\mathrm{Ni}$ & 0.16 & -0.34 & 0.04 & -0.79 & -0.31 & -0.72 & -0.31 & 0.79 & 0 & 1 & & & \\
\hline $\mathrm{Mn}$ & -0.33 & 0.12 & -0.45 & -0.50 & 0.19 & -0.54 & 0.07 & 0.64 & 0 & 0.86 & 1 & & \\
\hline $\mathrm{Zn}$ & -0.40 & 0.41 & -0.36 & 0.91 & 0.83 & 0.76 & 0.96 & -0.18 & 0 & -0.54 & -0.19 & 1 & \\
\hline $\mathrm{Pb}$ & -0.48 & 0.55 & -0.41 & 0.96 & 0.80 & 0.80 & 0.83 & -0.47 & 0 & -0.76 & -0.39 & 0.94 & 1 \\
\hline Dry & & & & & & & & & & & & & \\
\hline $\mathrm{NO}_{3}^{-}$ & 1 & & & & & & & & & & & & \\
\hline $\mathrm{PO}_{4}{ }^{2-}$ & 0.05 & 1 & & & & & & & & & & & \\
\hline $\mathrm{SO}_{4}^{2-}$ & 0.51 & -0.38 & 1 & & & & & & & & & & \\
\hline $\mathrm{Ca}$ & -0.41 & 0.02 & -0.65 & 1 & & & & & & & & & \\
\hline $\mathrm{Na}$ & -0.39 & -0.17 & -0.81 & 0.74 & 1 & & & & & & & & \\
\hline $\mathrm{K}$ & 0.17 & -0.08 & -0.49 & 0.75 & 0.75 & 1 & & & & & & & \\
\hline $\mathrm{Fe}$ & -0.44 & -0.40 & -0.07 & -0.41 & 0.13 & -0.46 & 1 & & & & & & \\
\hline $\mathrm{Cu}$ & 0.03 & -0.37 & -0.39 & -2.03 & 0.65 & 0.38 & 0.56 & 1 & & & & & \\
\hline $\mathrm{Cd}$ & 0 & 0 & 0 & 0 & 0 & 0 & 0 & 0 & 1 & & & & \\
\hline $\mathrm{Ni}$ & -0.19 & -0.28 & -0.68 & 0.64 & 0.97 & 0.80 & 0.13 & 0.76 & 0 & 1 & & & \\
\hline $\mathrm{Mn}$ & -0.62 & -0.10 & -0.87 & 0.60 & 0.93 & 0.47 & 0.39 & 0.64 & 0 & 0.85 & 1 & & \\
\hline $\mathrm{Zn}$ & -0.26 & -0.4 & -0.57 & 0.74 & 0.94 & 0.81 & 0.06 & 0.62 & 0 & 0.95 & 0.79 & 1 & \\
\hline $\mathrm{Pb}$ & 0.60 & 0.59 & -0.33 & 0.16 & 0.18 & 0.58 & -0.57 & 0.16 & 0 & 0.26 & 2.19 & 0.08 & 1 \\
\hline
\end{tabular}

\section{Chemometric Analysis}

Contamination factor: The contamination factor were employed to check the rate of individual metal contamination in the water samples. Contamination factor were calculated with the formula below.

$C f=\frac{\text { cmetal }}{C_{\text {background }}}$

Where Cf signify contamination factor, Cmetal represent the concentration of heavy metal and $\mathrm{C}_{\text {background }}$ signify the background value of metal. WHO recommendations for safe drinking water are taken as the background values for water sample. 
Table 3: Contamination factor ranking

\begin{tabular}{ll}
\hline Cf values & Contamination factor level \\
\hline $\mathbf{C}_{\mathbf{f}}<\mathbf{1}$ & Low contamination \\
$\mathbf{1} \leq \mathbf{C}_{\mathbf{f}}<\mathbf{3}$ & Moderate contamination \\
$\mathbf{3} \leq \mathbf{C}_{\mathbf{f}}<\mathbf{6}$ & Considerable contamination \\
$\mathbf{6} \leq \mathbf{C}_{\mathbf{f}}$ & Very high contamination \\
\hline
\end{tabular}

Pollution load index (PLI): The suggested pollution load index through Tomlinson for identifying pollution levels in soil were applied to the water samples to identify the concentration of contamination of heavy metal in the diverse locations. The PLI estimates the metal concentration status and give an idea of the various actions that can be taken to curb the issue (Naruka and Sharma, 2017). Researchers have estimated the pollution load index using equation 3.

$$
P L I=\sqrt[n]{C_{f 1} \times C_{f 2} \times C_{f 3} \times \ldots C_{f n}}
$$

A PLI value > 1 point toward an instantaneous intervention to ameliorate pollution; a PLI value < 1 specifies that extreme rectification procedures are not needed.

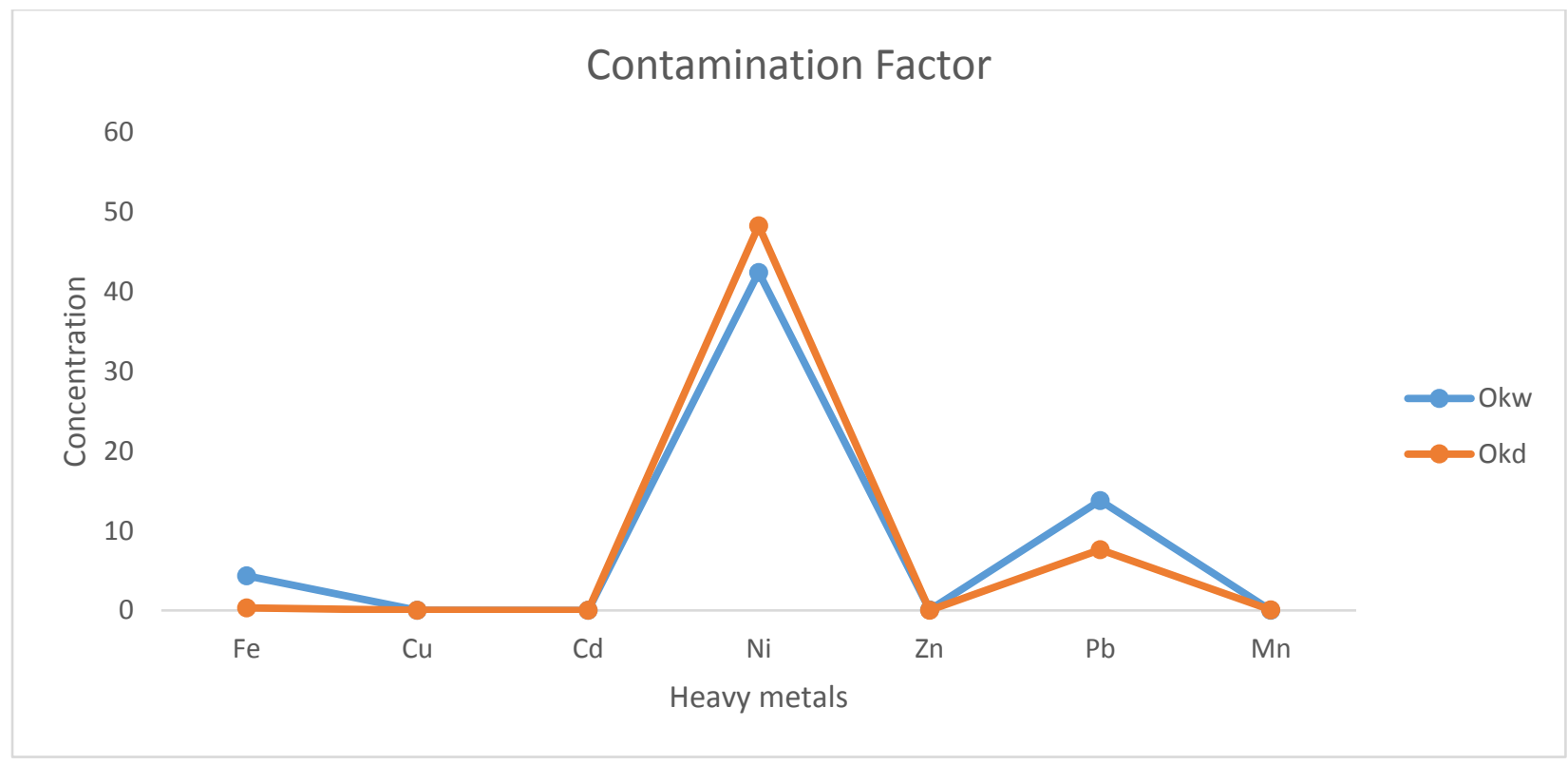

Figure 3: Contamination factor of heavy metals in wet (Okw) and dry (Okd) seasons.

Very high contamination factor was exhibited by $\mathrm{Ni}$ and $\mathrm{Pb}$ during the wet and dry whereas Fe in wet season shows considerably contaminated for all the sampling locations. Low contamination factor was exhibited by $\mathrm{Cu}, \mathrm{Cd}, \mathrm{Zn}$ and $\mathrm{Mn}$ in all the sampling locations for both wet and dry seasons. All samples showed low PLI for dry and wet season which point out that there are low pollution within the study area. However, there is need to constantly evaluate the water source in this locations. Moderate phosphate toxicity that takes lengthier time to advance can lead to the accumulation of calcium phosphate crystals in different tissues, comprising fatal cardiovascular calcification. 


\section{Water quality index (WQI)}

WQI is an arithmetic expression used to transmute large number of adjustable data into a single number, which signify the water quality level. The WQI is developed from the following formula conferring to Duru et al., 2017.

$W i=\frac{w_{i}}{\sum_{i=1}^{n} w i}$

Where: where, Wi is equal to the comparative weight, wi is equal to the weight of every single parameter and $\mathrm{n}$ is the number of parameters. Water quality evaluation may be developed conferring to Bordalo et al., 2006.

$q i=\frac{C_{I}}{S_{I}} \times 100$

Where qi is the quality ranking, $\mathrm{Ci}$ is the concentration of each chemical parameter in every single water sample in $\mathrm{mg} / \mathrm{L}$, and $\mathrm{Si}$ is the WHO drinking water quality standard. To work out the WQI, the SI was established for each chemical parameter, which is then used to determine the WQI using Equation 5 and 6. The overhead equation becomes:

$S I_{i}=W_{i} \times q_{i}$

$W Q I=\sum S I$

SIi is the sub-index of ith parameter, qi is the rating based on concentration of ith parameter and $\mathrm{n}$ is the number of parameters. The benchmark values were acquired from World Health Organization (WHO) standard for drinking water, 2007. The following point out the arrangement of (WQI) and the quality of water WQI

Table 4: Water Quality Index Values.

\begin{tabular}{ll}
\hline Cf Value & Water Quality \\
\hline $\mathrm{WQI}<50$ & Excellent water quality \\
$50<\mathrm{WQI} \leq 100$ & Good water quality \\
$100<\mathrm{WQI} \leq 200$ & Poor water quality \\
$200<\mathrm{WQI} \leq 300$ & Very poor water quality \\
$\mathrm{WQI}>300$ & Unsuitable for drinking \\
\hline
\end{tabular}

\section{Water Quality Index}

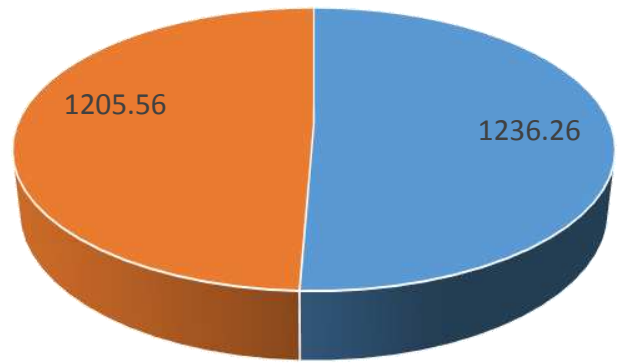

Figure 4: WQI values of the sampling points in wet and dry seasons 
From the results obtained and presented on the Figure 4 above for wet and dry season, all are above the estimated level for good drinking water quality which showed that selected water supplies in this studied area are severely polluted with physicochemical tracers for the reason that the calculated value 1205.56 for wet and 1236.26 for dry season. Various activities around the sampling point might have contaminated the rivers in an intense way.

\section{Assessment of health risk}

Dermal and ingestion exposure, Hazard quotient (HQ), Hazard Indices (HI)

Health risk through human exposure to these metals contamination can be either by means of dermal ingestion, inhalation or absorption, which are the normal contact passageways to the water. Subsequently all the River studied in this research are continually used by the people for the most part of their domestic activities and recreational activities. The calculation of health risk was calculated using equation 7 and 8 according to the USEPA risk estimation method (USEPA 1989).

$E x p_{\text {ing }}=\frac{C_{\text {water }} \times I R \times E F \times E D}{B W \times A T}$

$E x p_{\text {derm }}=\frac{C_{\text {water }} \times S A \times K P \times E T \times E F \times E D \times C F}{B W \times A T}$

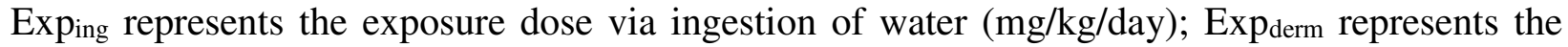
exposure dose via dermal absorption ( $\mathrm{mg} / \mathrm{kg} /$ day); $\mathrm{C}_{\text {water: }}$ show the average level of the estimated metals in water $(\mu \mathrm{g} / \mathrm{L})$; IR shows the ingestion level in this study $(2.2 \mathrm{~L} /$ day for adults; $1.8 \mathrm{~L} /$ day for children); EF shows the exposure frequency (365 days/year); ED shows the exposure duration (70 years for adults; and 6 years for children); BW show the average body weight (70 kg for adults; $15 \mathrm{~kg}$ for children); AT shows the averaging time (365 days/year $\times 70$ years for an adult; 365 days/year $\times 6$ years for a child); SA shows the exposed skin area $(18,000 \mathrm{~cm} 2$ for adults; 6600 $\mathrm{cm} 2$ for children); Kp shows the dermal permeability coefficient in water, $(\mathrm{cm} / \mathrm{h}), 0.001$ for $\mathrm{Cu}$, $\mathrm{Mn}, \mathrm{Fe}$ and $\mathrm{Cd}$, whereas 0.0006 for $\mathrm{Zn}$; 0.0001 for $\mathrm{Ni}$; and 0.004 for $\mathrm{Pb}$; ET shows the exposure time $(0.58 \mathrm{~h} /$ day for adults; $1 \mathrm{~h}$ /day for children) and $\mathrm{CF}$ shows the unit conversion factor $(0.001$ $\mathrm{L} / \mathrm{cm} 3$ ) (USEPA, 2009). Potential non-carcinogenic risks in line for exposure of heavy metals were established by evaluating the calculated contaminant exposures from each exposure path (ingestion and dermal) with the proposal dose (USEPA, 1989) using equation 9 below adequate to obtain hazard quotient (HQ) toxicity potential of an average daily intake to reference dose for an individual via the two fold pathways.

$H Q_{\text {ing } / \text { derm }}=\frac{E x p_{\text {ing } / \text { derm }}}{R f D_{\text {ing } / \text { derm }}}$

Where $\mathrm{RfD}_{\text {ing/derm }}$ represents the ingestion and dermal toxicity recommendation dose ( $\left.\mathrm{mg} / \mathrm{kg} / \mathrm{day}\right)$. The RfD derm and $\mathrm{RfD}_{\text {ing }}$ values were gotten from the literature (Wu et al., 2009). An HQ under 1 is presumed to be safe and taken as substantial non-carcinogenic (USEPA, 2019). The hazard index (HI) was calculated using the formula in equation 10

$H I=\sum_{i=1}^{n} H Q$

Where $\mathrm{HI}_{\mathrm{ing}} / \mathrm{derm}$ is hazard index through dermal contact or ingestion. 
Table 5: Dermal and ingestion exposure $(\mathrm{mg} / \mathrm{kg} / \mathrm{day})$ for adults and children both in wet and dry season

\begin{tabular}{|c|c|c|c|c|c|c|c|c|c|c|}
\hline & & & Wet & & & & Dry & & & \\
\hline Metals & RfD derm & RfDing & $\begin{array}{l}\mathrm{EXP}_{\text {derm }} \\
\text { (Adult) }\end{array}$ & $\begin{array}{l}\text { EXP derm } \\
\text { (Children) }\end{array}$ & $\begin{array}{l}D_{\text {ing }} \\
\text { (Adult) }\end{array}$ & $\begin{array}{l}\text { Ding } \\
\text { (Children) }\end{array}$ & $\begin{array}{l}\mathrm{EXP}_{\text {derm }} \\
\text { (Adult) }\end{array}$ & $\begin{array}{l}\text { EXP }_{\text {derm }} \\
\text { (Children) }\end{array}$ & $\begin{array}{l}D_{\text {ing }} \\
\text { (Adult) }\end{array}$ & $\begin{array}{l}D_{\text {ing }} \\
\text { (Children) }\end{array}$ \\
\hline $\mathbf{F e}$ & 140 & 700 & $1.99 \mathrm{E}-4$ & $5.63 \mathrm{E}-4$ & $4.02 \mathrm{E}-2$ & $1.53 \mathrm{E}-1$ & $5.76 \mathrm{E}-5$ & $1.62 \mathrm{E}-4$ & $1.06 \mathrm{E}-2$ & $4.44 \mathrm{E}-2$ \\
\hline $\mathbf{C u}$ & 8 & 40 & $1.55 \mathrm{E}-6$ & $4.4 \mathrm{E}-6$ & $3.10 \mathrm{E}-4$ & $1.2 \mathrm{E}-3$ & $1.55 \mathrm{E}-6$ & $4.4 \mathrm{E}-6$ & $3.14 \mathrm{E}-5$ & $1.2 \mathrm{E}-3$ \\
\hline Cd & 0.5 & 0.025 & 0.00 & 0.00 & 0.00 & 0.00 & 0.00 & 0.00 & 0.00 & 0.00 \\
\hline $\mathbf{N i}$ & 5.4 & 20 & $1.52 \mathrm{E}-5$ & $4.31 \mathrm{E}-5$ & $3.08 \mathrm{E}-2$ & $1.17 \mathrm{E}-1$ & $1.6 \mathrm{E}-5$ & $4.53 \mathrm{E}-5$ & $3.23 \mathrm{E}-2$ & $1.23 \mathrm{E}-1$ \\
\hline Mn & 0.96 & 24 & $3.11 \mathrm{E}-6$ & $8.8 \mathrm{E}-6$ & $6.28 \mathrm{E}-4$ & $2.4 \mathrm{E}-3$ & $4.67 \mathrm{E}-6$ & $1.32 \mathrm{E}-5$ & $9.42 \mathrm{E}-4$ & $3.6 \mathrm{E}-3$ \\
\hline Zn & 120 & 300 & $2.1 \mathrm{E}-5$ & $5.8 \mathrm{E}-5$ & $6.91 \mathrm{E}-3$ & $2.64 \mathrm{E}-2$ & $1.77 \mathrm{E}-5$ & $5.01 \mathrm{E}-5$ & $5.97 \mathrm{E}-3$ & $2.28 \mathrm{E}-2$ \\
\hline $\mathbf{P b}$ & 0.42 & 1.4 & $6.85 \mathrm{E}-5$ & $1.93 \mathrm{E}-4$ & $3.45 \mathrm{E}-3$ & $1.32 \mathrm{E}-2$ & $4.36 \mathrm{E}-5$ & $1.23 \mathrm{E}-4$ & $2.2 \mathrm{E}-3$ & $8.4 \mathrm{E}-3$ \\
\hline
\end{tabular}

Table 6: Hazard quotient for potential non-carcinogenic risk (HQ) and cumulative hazard indices (HI) for each heavy metal present in wet and dry season for Adult and Children

\begin{tabular}{|c|c|c|c|c|c|c|c|c|}
\hline & wet & & & & dry & & & \\
\hline Metals & $\begin{array}{l}\mathrm{HQ}_{\text {derm }} \\
\text { (Adult) }\end{array}$ & $\begin{array}{l}\mathrm{HQ}_{\text {derm }} \\
\text { (children) }\end{array}$ & $\begin{array}{l}\text { HQ }_{\text {ing }} \\
\text { (Adult) }\end{array}$ & $\begin{array}{c}\mathrm{HQ}_{\text {ing }} \\
\text { (children) }\end{array}$ & $\begin{array}{l}\mathrm{HQ}_{\text {derm }} \\
\text { (Adult) }\end{array}$ & $\begin{array}{l}\mathrm{HQ}_{\text {derm }} \\
\text { (children) }\end{array}$ & $\begin{array}{l}\mathrm{HQ}_{\text {ing }} \\
\text { (Adult) }\end{array}$ & $\begin{array}{c}\mathrm{HQ}_{\text {ing }} \\
\text { (children) }\end{array}$ \\
\hline $\mathbf{F e}$ & $1.42 \mathrm{E}-6$ & $4.02 \mathrm{E}-6$ & $5.74 \mathrm{E}-5$ & $2.1 \mathrm{E}-4$ & 4.11E-7 & $1.15 \mathrm{E}-6$ & $1.51 \mathrm{E}-5$ & $6.28 \mathrm{E}-5$ \\
\hline $\mathbf{C u}$ & $1.3 \mathrm{E}-7$ & $5.5 \mathrm{E}-7$ & $7.75 \mathrm{E}-6$ & $3 E-5$ & $1.93 \mathrm{E}-7$ & $5.5 \mathrm{E}-7$ & $7.85 \mathrm{E}-7$ & $3 \mathrm{E}-5$ \\
\hline Cd & 0.00 & 0.00 & 0.00 & 0.00 & 0.00 & 0.00 & 0.00 & 0.00 \\
\hline $\mathbf{N i}$ & $2.8 \mathrm{E}-6$ & $7.98 \mathrm{E}-6$ & $1.54 \mathrm{E}-3$ & $5.85 \mathrm{E}-3$ & $2.96 \mathrm{E}-6$ & $8.38 \mathrm{E}-6$ & $1.61 \mathrm{E}-3$ & $6.15 \mathrm{E}-3$ \\
\hline Mn & $3.23 \mathrm{E}-6$ & $9.16 \mathrm{E}-6$ & $2.61 \mathrm{E}-5$ & $1 \mathrm{E}-4$ & $4.86 \mathrm{E}-6$ & $1.37 \mathrm{E}-5$ & $3.94 \mathrm{E}-5$ & $1.5 \mathrm{E}-4$ \\
\hline Zn & $1.75 \mathrm{E}-7$ & 4.82E-7 & $2.3 \mathrm{E}-5$ & $8.8 \mathrm{E}-5$ & $1.47 \mathrm{E}-7$ & 4.17E-7 & $1.99 \mathrm{E}-5$ & 7.6E-5 \\
\hline $\mathbf{P b}$ & $1.63 \mathrm{E}-4$ & $4.59 \mathrm{E}-4$ & $2.46 \mathrm{E}-3$ & $9.42 \mathrm{E}-3$ & $1.03 \mathrm{E}-4$ & $2.92 \mathrm{E}-4$ & $1.57 \mathrm{E}-3$ & $6 \mathrm{E}-3$ \\
\hline HI & $1.7 \mathrm{E}-4$ & $4.8 \mathrm{E} 4$ & $2.62 \mathrm{E}-2$ & $1.56 \mathrm{E}-2$ & $1.11 \mathrm{E}-4$ & $3.16 \mathrm{E}-4$ & $3.25 \mathrm{E} 3$ & $1.24 \mathrm{E}-2$ \\
\hline
\end{tabular}

The dermal and ingestion exposure calculated in table 5 were used to determine the hazard quotient in table 6. The hazard quotient (HQ) was determined and both HQderm and HQing in the two seasons for all the trace metals checked in the research were less than one (1) as demonstrated in Table 6 for adults and children. This demonstrates there is practically no adversative health impact expected to be enacted by any of these metals when the surface water is utilized. The HQing and HQderm diminished in the order of lead > zinc > copper > iron > nickel > manganese and lead > iron $>$ nickel $>$ copper $>$ zinc $>$ manganese $>$ cadmium, for both children and adults in wet season, respectively. HQin and HQderm diminished in the order of nickel $>$ lead $>$ manganese $>$ copper $>$ zinc $>$ iron and lead $>$ zinc $>$ nickel $>$ copper $>$ manganese $>$ iron $>$ for both children and adults in dry season, respectively. Nevertheless, it has been recommended that estimated HQ values for metals > 1 for children should not be disregarded (Giandomenico et al., 2017; Sudsandee et al., 2017), probably because, children are vastly disposed to pollutants (Sudsandee et al. 2017). The major sources of non-carcinogenic health risk in both passageways were $\mathrm{Pb}, \mathrm{Zn}$ and $\mathrm{Ni}$. The estimated total HQ values were less than one as seen in table 6.

\section{Chronic daily intake (CDI) and Carcinogenic risk (CR)}

The carcinogenic risk (CRing) shows an incremental chance that an individual will develop cancer during his lifetime inferable from revelation under characterized conditions were computed for the selected metals in this current examination (Wu et al. 2009; Ibe et al., 2020). 
The chronic daily consumption of heavy metals through ingestion was computed using equation 11.

$C D I=C_{\text {water }} \times \frac{D I}{B W}$

Where $\mathrm{C}_{\text {water }}$ represents the concentration of trace metal in water in $(\mathrm{mg} / \mathrm{L}), \mathrm{DI}$ imply the, average daily intake of water $(2.2 \mathrm{~L}$ per day for adults; $1.8 \mathrm{~L}$ per day for children) and BW shows the whole body weight (70 kg for adults; $15 \mathrm{~kg}$ for children), correspondingly (Yonglong et al. 2015). The cancer risk (CR) was calculated using the formula in equation 12 below:

$C R_{\text {ing }}=\frac{D_{\text {ing }}}{S F_{\text {ing }}}$

Where $\mathrm{SF}_{\text {ing }}$ represent the cancer slop factor. The $\mathrm{SF}_{\text {ing }}$ for $\mathrm{Pb}$ is $8.5 \mathrm{mg} / \mathrm{kg} / \mathrm{day}$ (USEPA 1989 , 2005; Naveedullah et al., 2010; Ibe et al., 2020).

Table 7: Chronic risk assessment (CDIing) of heavy metals for both seasons in adults and children

\begin{tabular}{ccccc}
\hline \multicolumn{1}{c}{ wet } & \multicolumn{3}{c}{ dry } \\
\hline Metals & $\begin{array}{c}\text { CDI } \\
\text { (Adult) }\end{array}$ & $\begin{array}{c}\text { CDI } \\
\text { (children) }\end{array}$ & $\begin{array}{c}\text { CDI } \\
\text { (Adult) }\end{array}$ & $\begin{array}{c}\text { CDI } \\
\text { (children) }\end{array}$ \\
& $3.89 \mathrm{E}-2$ & $1.4 \mathrm{E}-1$ & $1.16 \mathrm{E}-2$ & $4.44 \mathrm{E}-2$ \\
$\mathbf{C u}$ & $3.14 \mathrm{E}-4$ & $1.2 \mathrm{E}-1$ & $3.14 \mathrm{E}-4$ & $1.2 \mathrm{E}-3$ \\
$\mathbf{C d}$ & 0.00 & 0.00 & 0.00 & 0.00 \\
$\mathbf{N i}$ & $3.07 \mathrm{E}-2$ & $1.17 \mathrm{E}-1$ & $3.23 \mathrm{E}-2$ & $0.12 \mathrm{E}-1$ \\
$\mathbf{M n}$ & $6.28 \mathrm{E}-4$ & $2.4 \mathrm{E}-3$ & $9.42 \mathrm{E}-4$ & $3.6 \mathrm{E}-3$ \\
$\mathbf{Z n}$ & $6.9 \mathrm{E}-3$ & $2.64 \mathrm{E}-2$ & $5.96 \mathrm{E}-3$ & $2.28 \mathrm{E}-2$ \\
$\mathbf{P b}$ & $3.45 \mathrm{E}-3$ & $1.32 \mathrm{E}-2$ & $2.19 \mathrm{E}-3$ & $8.4 \mathrm{E}-3$ \\
\hline
\end{tabular}

The CDI indices for heavy metals during the study period for both ages were found to be in the order of $\mathrm{Fe}>\mathrm{Ni}>\mathrm{Zn}>\mathrm{Pb}>\mathrm{Cu}>\mathrm{Mg}$ in wet season; and $\mathrm{Ni}>\mathrm{Zn}>\mathrm{Fe}>\mathrm{Pb}>\mathrm{Cu}>\mathrm{Mn}>\mathrm{Cd}$ in dry season (Table 7). This suggests that the surface water assumes less health threats to both adults and children via the pathways, however procedures ought to be made to circumvent accumulation of heavy metals that possibly will pose health problems especially in children.

Table 8: Carcinogenic risk assessment (CRing) of Pb for wet and dry season for both adults and children

\begin{tabular}{lllll}
\hline Metal & wet & & dry & \\
\hline & Adult & Children & Adult & Children \\
$\mathbf{P b}$ & $4.05 \mathrm{E}-4$ & $1.55 \mathrm{E}-3$ & $2.57 \mathrm{E}-4$ & $9.88 \mathrm{E}-4$ \\
\hline
\end{tabular}

Table 8 above present the carcinogenic risk of $\mathrm{Pb}$ for Okumpi calculated for both adults and children for both wet and dry season, for the reason that the value of carcinogenic slope factor for other metals could not be traced in literatures, only lead was calculated. Under extreme regulatory program the carcinogenic risk values between $10^{-6}$ and $10^{-4}$ could pose potential risk to an individual, therefore the results in this current study showed that the level of $\mathrm{Pb}$ in the surface water could pose carcinogenic risk to both adults and children. 


\section{Conclusion}

The current study has uncovered that some actual appearance of surface water from Okumpi River during the wet and dry season are not in line with WHO guidelines. The study has shown additionally that the $\mathrm{pH}$ of all the sampling point are acidic. Phosphate apparently is a bit high in all the sampling point at various season and this can be related with high utilization of more phosphate grounded fertilizer on farm lands surrounding the Rivers. The current study has uncovered that the surface waters are profoundly contaminated with $\mathrm{Fe}, \mathrm{Ni}, \mathrm{Pb}$, also this current study has shown that the surface water is not suitable for drinking purposes as revealed by the high water quality index (> 300).

\section{Recommendation}

With regard to the results on the present study, the following recommendations are made:

1. The water resources monitoring in the Nwangele Local Government area ought to be done regularly in order to assess pollution levels in order to check the spread of water related complications especially in Okumpi River.

2. In a circumstance of uncertain water quality, treatment is suggested through filtration, boiling and the use of additive (alum, liming, chlorine), thereby reducing the risk of water-related problems.

\section{References}

Anudike, J., Duru, M. and Uhegbu, F. (2019). Water quality assessment of Nwangele River in Imo State, Nigeria. Journal of Ecobiotechnology, 11: 1-5

Bernice, N. C., Veronica, O. E., Samuel, Keyna, E. S. and Nwachukwu, C. (2013). Assessment of water quality and its effect on the health of residents International Letters of Natural Sciences 4 (2013) 34-43.

Bordalo, A. A., Teixerra, R. and Wiebe, W. J. (2006). Water quality index applied to an international shared river basin: the case of Douro River. Environ. Manage; 38(6):910920.

Duru, C. E., Okoro, I. P. and Enyoh, C. E. (2017). Quality Assessment of Borehole Water within Orji Mechanic Village Using Pollution and Contamination Models. International Journal of Chemical, Material and Environmental Research, 4 (3): 123-130

Gannon, R. W., Osmond, D. L., Humenik, F. J. and Gale, J. A. (2007). Quality water resource. Spooner, Journal of Agricultural Water, vol. 32, no. 3, pp. 437-450.

Giandomenico, S., Cardellicchio, N., Spada, L., Annicchiarico, C. and Di Leo, A. (2016). Metals and PCB levels in some edible marine organisms from the Ionian Sea: dietary intake evaluation and risk for consumers. Environ Sci Pollut Res 23(13):12596-12612

Ibe, F. C, Isiukwu, B. O. and Enyoh, C. E. (2020). Trace metals analysis of soil and edible plant leaves from abandoned municipal waste dumpsite in Owerri, Imo state, Nigeria. World News of Natural Sciences (WNOFNS). 2017; 13:27-42. 
Ihenetu, S. C., Enyoh C. E., Uzoigwe, A. D. and Ubah, O. G. (2018). Biophysical Characterization of Palm Oil Mill Effluent from Adapalm, Imo State Nigeria. International Journal of Environmental Studies.4 (1) 4.

Ihenetu, S. C., Ochule, B. I., Enyoh, E. C., Ibe, F. C. Verla, A. W. and Isiuku, B. O. (2020). Pollution and Health Risks Assessment of Ground Water Sources around a Waste Disposal Site in Owerri West Local government Area of Imo State. J. Mater. Environ. Sci., 2020, Volume 11, Issue 9, Page 1560-1573.

Ihenetu, S. C., Ihenetu, F. C. and Kalu G. I. (2017). Determination of Heavy Metals and Physicochemical Parameters of Crude Oil Polluted Soil from Ohaji Egbema Local Government in Imo State. Open Journal of Yangtze Gas and Oil. 2, 161-167.

Jinwal, A. and Dixit, S. (2008). Pre and post monsoon variation in physio-chemical characteristic in groundwater quality in Bhopal, India. Asian Journal of Experimental Sciences, 22(3), 311- 316.

Macdonald, D. W. and Christopher, E. O. (2011). Pollution studies on Nigerian rivers: heavy metals in surface water of warri river, Delta State. Journal of Biodiversity and Environmental Sciences. Vol. 1, No. 3, p. 7-12.

Naruka, S. and Sharma, M. S. (2017). Water quality assessment of Rajsamand Lake, Rajasthan, India, International Research Journal of environmental science. 2017; 6(6):22-28.

Naveedullah, M. Z. H., Yu, C., Shen, H., Duan, D. and Shen, C. (2014). Concentration and human health risk assessment of selected heavy metals in surface water of the siling reservoir watershed in Zhejiang Province, China. Pol J Environ Stud 23(3):801-811

Owa, F. D. (2013). Water pollution: sources, effects, control and management. Mediterranean journal of social sciences. 4(8):65-68.

Sudsandee, S., Tantrakarnapa, K., Tharnpoophasiam, P., Limpanont, Y., Mingkhwan, R. and Worakhunpiset, S. (2017). Evaluating health risks posed by heavy metals to humans consuming blood cockles (Anadara granosa) from the Upper Gulf of Thailand. Environ Sci Pollut Res 24(17):14605-14615

U.S. Environmental Protection Agency (2003). EPA's Report on the Environment (2003 Draft). [Retrieved December 28, 2013 from http://cfpub.epa.gov/ncea/cfm/recordisplay.cfm?deid=56830].

Ubuoh, E. A., Akhionbare, S. M. O., Ogbuji, S. and Akhionbare, W. N (2013). Effectiveness of Water Quality Index in Assessing Water resources Characteristics in Izombe, Oguta Local government Area Of Imo State, Nigeria. I.J.A.B.R., VOL.3 (1)2013:31-35.

Ugwu, E. I., Uzoma, N. E. and,Ikechukwu, E. L. (2016). Study on Physiochemical Parameters of Water Samples from Onuimo River Imo state, Nigeria. South Asian Journal of Engineering and Technology Vol.2, No.25 (2016) 1-8

Verla, A. W., Verla, E. N., Amaobi, C. E. and Enyoh, C. E. (2018). Water pollution scenario at river uramurukwa flowing through owerri metropolis, Imo state, Nigeria. International Journal of Advanced Scientific Research, 3 (3); 40-46

Yonglong, L., Song, S. and Wang, R. (2015). Impacts of soil and water pollution on food safety and health risks in China. International Journal of Environment. 77:5-15. World Health 
Organization (WHO), Guidelines for Drinking-Water Quality, 3rd Edition, World Health Organization (WHO), Geneva, 2004.

World Health Organization, (2006). Rapid Assessment of Drinking Water Quality. Country Report Nigeria

Wu B, Zhao DY, Jia HY, Zhang Y, Zhang XX, Cheng SP (2009) Preliminary risk assessment of trace metal pollution in surface water from Yangtze River in Nanjing Section, China. Bull Environ Contam Toxicol 82(4):405-409 


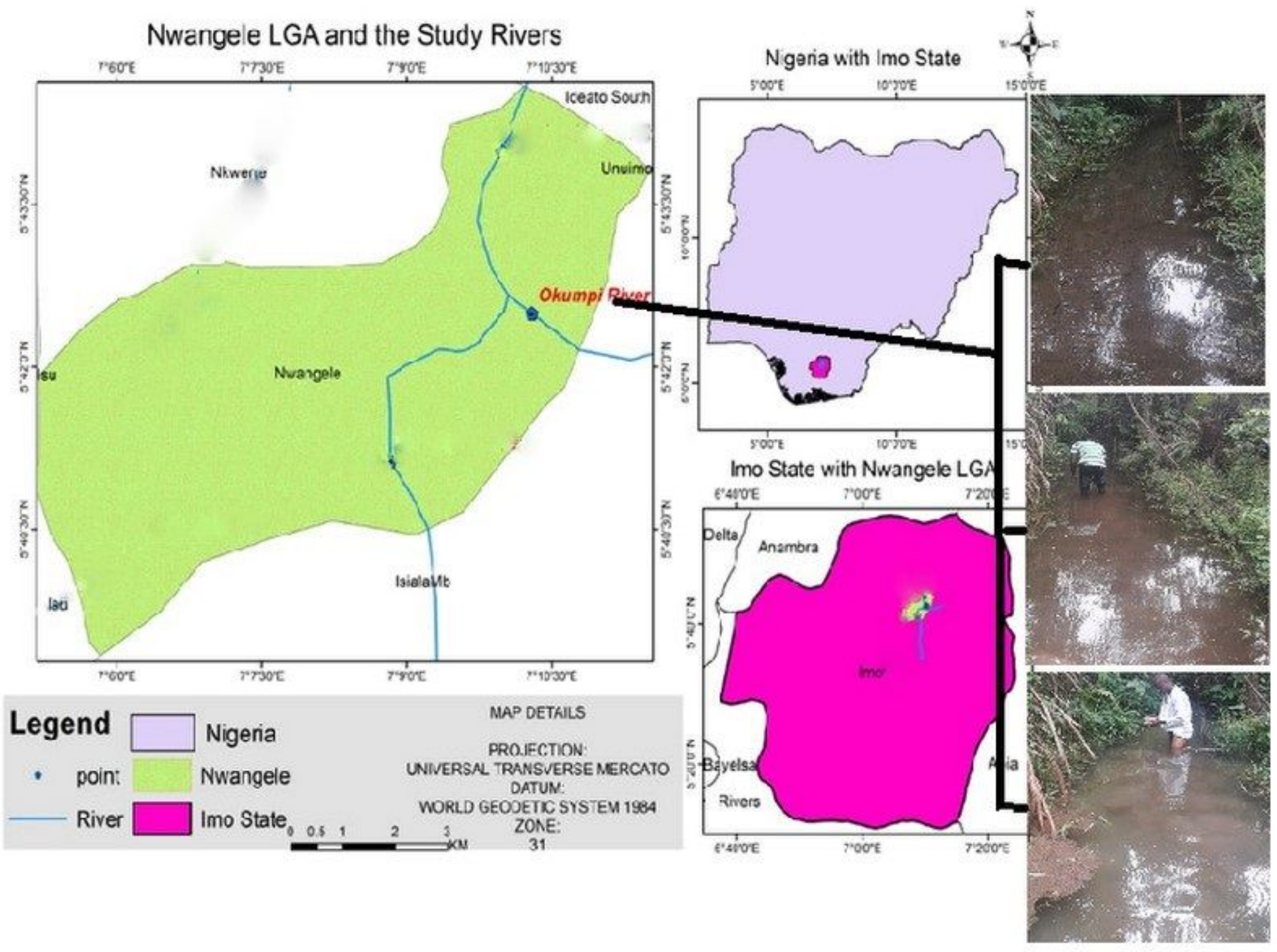

\section{Figure 1}

Map showing Okumpi River. Note: The designations employed and the presentation of the material on this map do not imply the expression of any opinion whatsoever on the part of Research Square concerning the legal status of any country, territory, city or area or of its authorities, or concerning the delimitation of its frontiers or boundaries. This map has been provided by the authors. 


\section{Distribution of heavy metals}

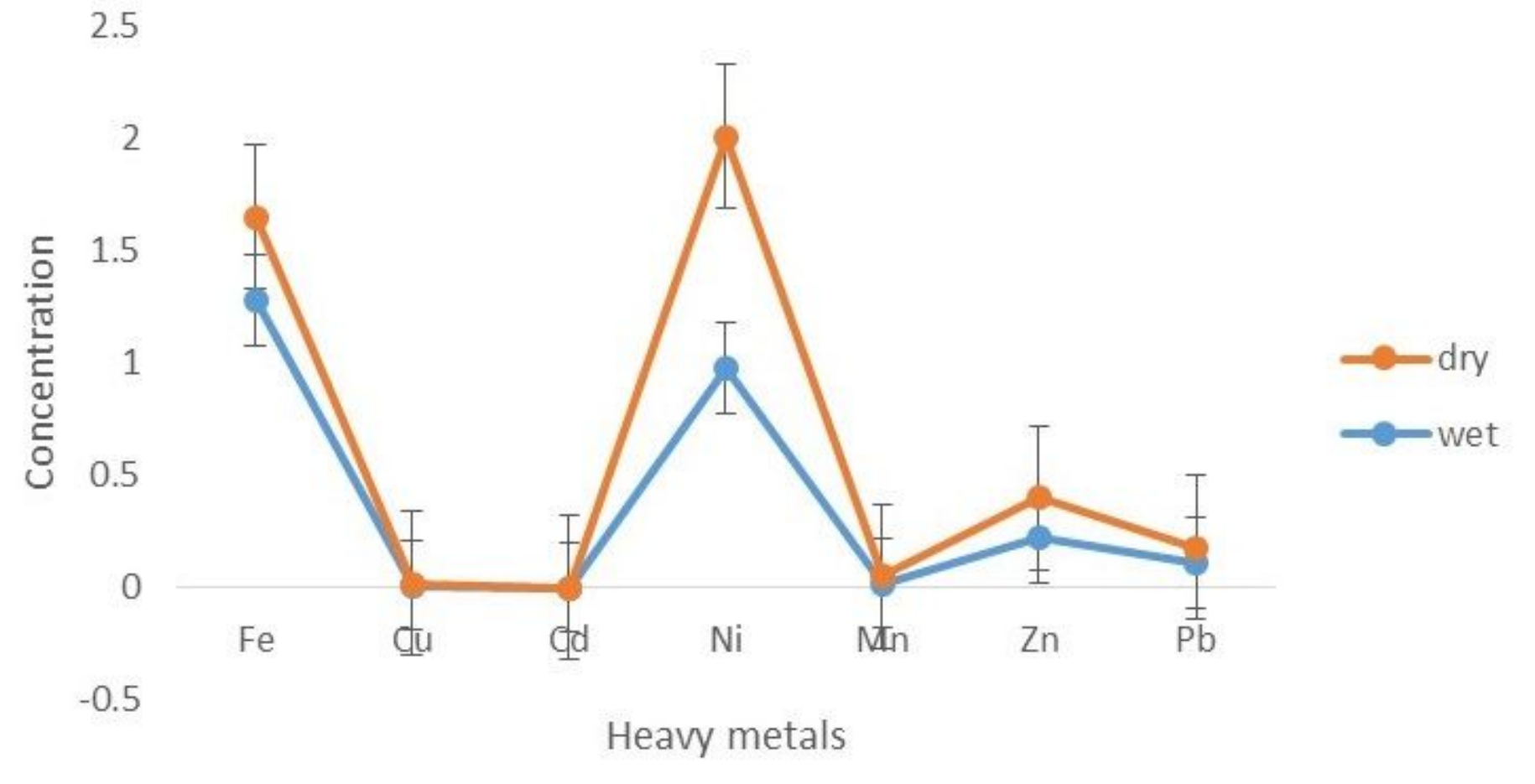

Figure 2

Line chart with error bars showing the distribution of heavy metal in wet and dry seasons

\section{Contamination Factor}

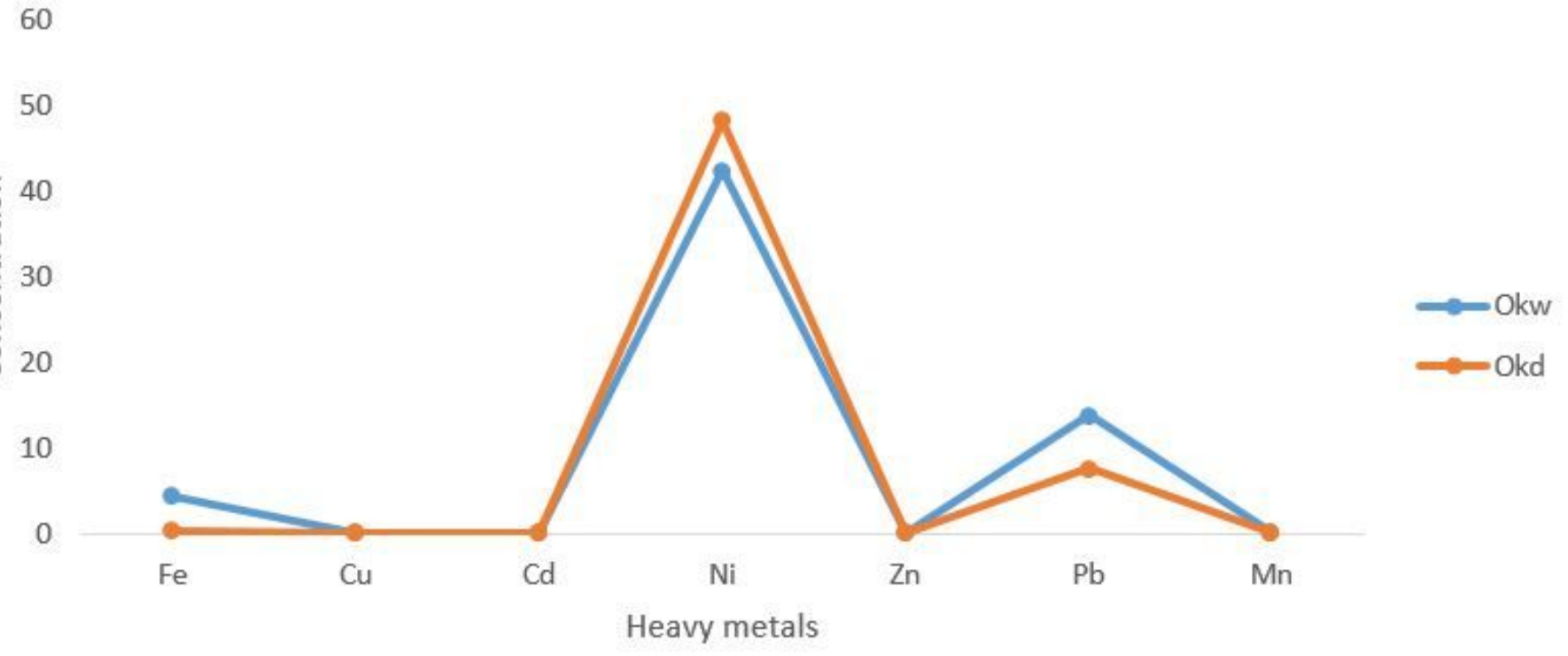

Figure 3 
Contamination factor of heavy metals in wet (Okw) and dry (Okd) seasons.

\section{Water Quality Index}

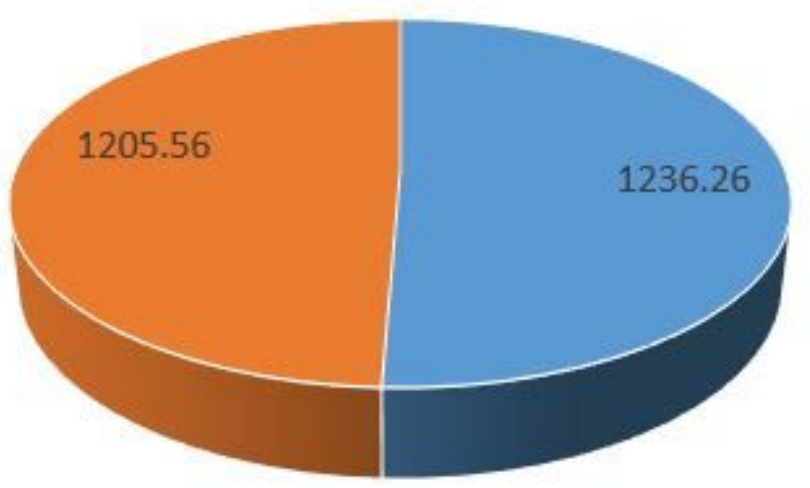

- Okw

- Okd

\section{Figure 4}

WQI values of the sampling points in wet and dry seasons 